\section{日本臨床外科学会愛知県支部抄録 (第45回愛知臨床外科学会)}

\author{
日 時: 平成28年 2 月11日（木）［建国記念の日］ \\ 会 場：愛知県医師会館 \\ A 会場 9 階 大講堂 \\ B会場 地階 健康教育講堂 \\ 会 長 : 加藤 岳人
}

\section{3 食道アカラシアに胃癌を合併した 1 例 西尾市民病院外科}

浿田琴巳、襧宜田政隆、上村孝法、藤竹信一、市川俊介、稲生照 久、岸田貴喜

食道アカラシアと胃癌の合併は報告例が少ない。今回我々は食道 アカラシアに胃体部進行胃癌を合併した 1 例を経験した。症例は 66歳男性。胸やけ、睡眠時の大量の流涎を主訴に来院。食道造影 で食道上部まで液体貯留と直線型の拡張、食道胃接合部の平滑な 狭小像と食道の異常運動の出現を認めた。内視鏡検査では上部か ら中部食道まで拡張と液体貯留を認め、下部食道に恒常的な狭窄 を認めたが食道癌はなく、内視鏡の食道胃接合部の通過は可能で あった。胃体中部から前庭部小弯に 2 型胃癌を認め、胃全摘術 (D 2 ）を行った。再建はRoux en Y法、食道空腸吻合はoverlap 法 で行った。術後経過は良好で初診時の主訴は消失した。

4 進行癌と術前診断した胃粘膜下囊胞を伴う胃粘膜癌の 1 例 名古屋第一赤十字病院一般消化器外科 山田真子、湯浅典博、竹内英司、後藤康友、三宅秀夫、永井英雄、 吉岡祐一郎、奥野正隆、細井敬泰、南 貴之、加藤哲朗、清水大 輔、加藤翔子、前田真吾、毛利康一、浅井真理子、深田浩志、宮 田完志

症例は66歳男性で、2014年 8 月、右季肋部痛を主訴に当院を受診 した。胃造影X線検查では幽門前庭部に深い不整な陥凹を認め、 上部消化管内視鏡検查では幽門前庭部小弯に隆起成分を伴う不整 な陷凹性病変を認め、生検で中分化型腺癌と診断された。以上よ り、cT 2 (MP), cN 0, M 0, cStage IBの進行癌と診断し、幽 門側胃切除を行った。切除標本肉眼所見では幽門前庭部小弯に35 $\mathrm{mm} \times 20 \mathrm{~mm}$ の不整形の浅い陥凹性病変を認めた。病理組織学的にク ロマチン豊富な核を有する異型細胞が比較的良く分化した異型腺 管構造を形成し増生した高分化型腺癌であり、胃粘膜下囊胞内を 置換性に進展していた。0-IIc, $35 \mathrm{~mm} \times 20 \mathrm{~mm}$, tub 2, T 1 a（M), ly 0 , v $0, \mathrm{~N} 0$ with gastritis cystica profunda と診断された。 胃粘膜下囊胞による病変の厚みを癌浸潤による厚みと考えたため 術前深達度診断を誤ったと考えられる。

\section{5 術前に悪性が疑われた胃神経鞘腫の 1 例} 春日井市民病院外科

原田貴仁、山口竜三、古田美保、渡邊真哉、會津恵司、井原 努、 玉井宏明、三輪知弘、有元淳記、榊原昌志、山中美歩、中橋剛一、 三竹泰弘、山本泰資

症例は75歳女性。吐血にて近医を受診した。高度貧血のため当院 へ紹介された。EGDでは胃角部大弯に頂部が潰瘍化した粘膜下 腫瘍を認めた。生検では紡錘形細胞の増殖を認め、免疫染色によ り胃神経鞘腫が疑われた。CTでは胃体部に造影効果のそしい 5.9 $\times 4.6 \mathrm{~cm}$ の腫瘤を認め、周囲の壁在には造影効果のある著明に腫 大したリンパ節を複数個伴っていたため、悪性神経鞘腫と術前診 断し、リンパ節郭清を伴う胃切除術を施行した。病理組織検查お よび免疫染色から神経鞘腫と診断されたが、悪性像は認めず、郭 清リンパ節には腫瘍細胞を認めなかった。術後経過は良好で術後 12日目に退院した。胃神経鞘腫は比較的まれなうえ、悪性が疑わ れることはめずらしいので報告する。 
6 Ball valve syndrome を呈した胃癌の 2 例 名古屋第一赤十字病院一般消化器外科

風間悠介、湯浅典博、竹内英司、後藤康友、三宅秀夫、永井英雅、 吉岡祐一郎、奥野正隆、細井敬泰、南 貴之、加藤哲朗、清水大 輔、加藤翔子、前田真吾、毛利康一、浅井真理子、樑田浩志、宮 田完志

症例 1 は73歳男性で平成 27 年 5 月、内視鏡検查 (GIS) で胃前庭 部後壁に中央のやや陥凹した発赤を伴う隆起性病変を認め、生検 で腺癌と診断された。CT、上部消化管造影UGIでこの腫瘤の 十二指腸への脱出を認めた。幽門側胃切除後の切除標本では $30 \times$ 20mm の 0-Is 型腫瘍で、病理組織学的に tub 2, T 1 b (SM 2 ), N0, M 0, Stage Iaであった。症例 2 は71歳男性で貧血のため GISを施行したところ、胃角大彎に多結節分葉状の亜有茎性腫瘍 を認めた。CTでこの胃腫瘤の十二指腸への脱出を認めた。幽門 側胃切除後の切除標本では $80 \times 50 \mathrm{~mm}$ の 0 -Ip で、病理組織学的 にtub $2>\operatorname{sig}$, T 1 a $(\mathrm{M}), \mathrm{N} 1$, M 0 , Stage IIaであった。

\section{7}

胃悪性リンパ腫に合併し深達度・リンパ節転移度診断 に苦慮した早期胃癌の 1 例

愛知県がんセンター中央病院消化器外科

林 大介、伊藤誠二、三澤一成、伊藤友一、小森康司、安部哲也、 千田嘉毅、木村賢哉、木下敬史、植村則久、夏目誠治、川上次郎、 清水泰博、木下 平

症例は34歳男性。体重減少を主訴に受診。胃体下部から幽門輪に 全周性の壁肥厚を伴う潰瘍性病変を認め、悪性リンパ腫と腺癌の 合併と診断。胃周囲リンパ節に転移が疑われた。悪性リンパ腫が 主体と考え、R-CHOP療法を 4 コース施行後胃切除の方針とし た。術中所見はT 3-N 2-M 0 で＃ 4 sbに硬く腫大したリンパ節 を認め胃全摘・脾摘術を行った。切除標本では粘膜に限局して腺 癌を認め悪性リンパ腫は完全に消退しリンパ節転移も認めなかっ た。胃癌と胃悪性リンパ腫の合併はまれであり、リンパ腫治療後 のため胃癌の深達度・リンパ節転移度診断に苦慮した 1 例を経験 したので報告する。

8 診断に難渋した、初回手術後十年目に胸水貯留を契機 に発見された再発胃癌の一例

小牧市民病院外科

植村友稔、望月能成、田中健士郎、笹原正寬、上嶋三千年、鈴木 雄之典、長谷川和也、佐藤雄介、間下優子、田中恵理、井戸田愛、 村上弘城、神崎章之、横山裕之、谷口健次

症例は60歳代女性。2005年に胃癌に対して幽門側胃切除術施行さ れ、術後 2 年間S- 1 による補助化学療法を施行、再発所見認め ず2010年フォロー終了。

2015年検診にて右胸水貯留を指摘、内科受診。胸腔精查にて悪性 所見認めず。CT検查にて卵巣腫大が指摘されたためMeigs 症候 群を疑い、子宮、両側卵巣摘出術施行。右卵巣の病理の結果、胃 癌の再発転移と診断された。心囊水貯留も認め、穿刺細胞診の結 果陽性であった。

胃癌、卵巣転移、心膜転移の診断にてS-1 単独療法施行。施行 後は症状増悪認めず、現在外来通院中である。診断に難渋した、 胸水貯留を契機に発見された再発胃癌の症例を経験したので報告 する。
9 胃切後 stomal polypoid hypertrophic gastritisに合併 した微小癌の 1 例

名古屋第一赤十字病院一般消化器外科

水野宏論、湯浅典博、竹内英司、後藤康友、三宅秀夫、永井英雅、 吉岡裕一郎、奥野正隆、細井敬泰、南 貴之、加藤哲朗、清水大 輔、加藤翔子、前田真吾、毛利康一、浅井真理子、深田浩志、宮 田完志

症例は78歳男性で、40年前に十二指腸潰瘍にて幽門側胃切除、 B-II法再建を受けている。平成 26 年 6 月、血便を主訴に当院を 受診した。上部消化管内視鏡検查にて胃空腸吻合部口側は全周性 に発赤を伴って隆起し、生検で再生異型上皮と診断された。 2 力 月後、この隆起は平血状を呈し、5 月月後、表面のびらん面が大 きくなった。13力月後、この部分からの生検で高分化型腺癌と診 断されたため残胃全摘術を施行した。切除標本では胃空腸吻合部 が多結節状隆起を形成し、隆起部分全部が腫瘍性病変のように観 察された。吻合部を全割し検索したところ、病理組織学的に粘膜 下に囊胞性に拡張する腺管や腺管構造、その表層に高分化型腺癌 を認め、胃切後 stomal polypoid hypertrophic gastritisに伴なっ た微小癌（大きさ $3 \mathrm{~mm} 、 \mathrm{pM}, \mathrm{pN} 0$ ）であった。

10 1 例 十二指腸第 4 部憩室出血に対し、憩室切除を施行した 春日井市民病院外科

田中伸和、山口竜三、古田美保、渡邊真哉、會津恵司、井原 努、 玉井宏明、三輪知弘、有元淳記、山中美歩、榊原昌志、中橋剛一、 三竹泰弘、山本泰資

症例は82歳、女性。主訴は黒色便。前医の上下部消化管内視鏡検 查で出血源は不明とされたが、持続する下血のため、ショックと なり当科へ転院された。来院時 $\mathrm{Hb} 5.8 \mathrm{~g} / \mathrm{dL}$ と高度貧血を認めた。 前医の造影 $\mathrm{CT}$ を見直すと十二指腸第 4 部に䅣室を認め、内腔に 高吸収域の液体貯留を伴っていた。ここが出血源と診断し、ダブ ルバルーン内視鏡で確認後、手術を施行した。トライツ勒帯を切 離し、後腹膜の十二指腸第 4 部憩室を同定した。息室のみ切除し、 縫合閉鎖した。術後 5 日で退院した。十二指腸憩室は $80 \%$ 以上が 下行脚に存在する。また十二指腸悡室出血は上部消化管出血のわ ずか $0.07 \%$ と報告されている。したがって第 4 部悡室出血は極め てまれといえる。

11 膵石を合併した膵管内乳頭粘液性腫瘍の一例 名古屋第一赤十字病院一般消化器外科

浅井真理子、湯浅典博、竹内英司、後藤康友、三宅秀夫、永井英 雅、吉岡裕一郎、奥野正隆、細井敬泰、南 貴之、加藤哲朗、清 水大輔、加藤翔子、前田真吾、毛利康一、樑田浩志 症例は68歳男性で既往に糖尿病・前立腺肥大症がある。2015年 4 月、前立腺肥大症で通院中の CT で膵腫瘍を指摘され当院を受診 した。初診時の腹部CTでは膵頭部腹側に突出する大きさ $25 \times$ $22 \mathrm{~mm}$ の低吸収性腫瘤と、その内部には粗大な石灰化を認めた。 $\mathrm{MRCP} \cdot \mathrm{ERCP}$ ではこの腫瘤は多房性囊胞で主膵管との交通を認 めたため、分枝型IPMN と診断し亜全胃温存膵頭十二指腸切除術 を行った。切除標本では拡張した分枝膵管内に不整形の白色の膵 石を認め、組織学的にIPMN with low grade dysplasiaと診断さ れた。膵石の成分分析では $98 \%$ 以上が炭酸カルシウムであった。 
12 膵癌との鑑別に難渋した自己免疫性膵炎の 1 例 名古屋第二赤十字病院外科

岡本眞宗、坂本英至、法水信治、赤羽和久、新宮優二、田口泰郎、 渡邊博行、中村勇人、米川佳彦、秋田由美子、大原規彰、河野秀 俊

症例は67歳女性。発熱と左上腹部痛を主訴に近医受診。単純 CT で脾膿瘍と診断され当院紹介受診した。当院で施行したMRI、 ERCPでは膵尾部癌が疑われた。造影 CTで全身のリンパ節腫脤 を認めたため、腋窩リンパ節生検を施行。病理検查で $\operatorname{IgG} 4$ 関連 リンパ節症と診断された。膵尾部の病変は、画像上膵癌を否定出 来なかったため、膵体尾部切除術を施行。術中所見で膵体尾部の 硬化と、8 a、11リンパ節の腫脹を認めた。病理検査で囊胞は脾 より発生し内部に腫瘍成分を認めなかった。膵、リンパ節の免疫 染色でそれぞれ IgG 4 関連自己免疫性膵炎、IgG 4 関連リンパ節 症と診断された。リンパ節炎、膵炎、脾囊胞が併存し、診断に難 渋した 1 例を報告する。

13 腹膜播種を伴う膵体部癌に対し Gemcitabine 投与し切 除した一例 愛知県がんセンター中央病院消化器外科部

重吉 到、夏目誠治、千田嘉毅、伊藤誠二、小森康司、安部哲也、 三澤一成、伊藤友一、木村賢哉、木下敬史、植村則久、川上次郎、 清水泰博

症例は71歳の男性。近医のCTで膵体部腫湟を指摘され、紹介受 診した。膵体部癌と診断し、2012年10月手術を施行した。開腹所 見で、骨盤内後腹膜に 1 個、小腸間膜に 2 個の腹膜結節を認めた。 これらを切除し、迅速病理検查に提出したところ腺癌の転移と診 断されたので、原発巣は非切除とした。腹膜播種を伴う膵体部癌 としてGemcitabine 1,000mg/m² 21 コース投与した。2014年 6 月、CT、PETCTに扔いて新規病変の出現や播種病変を認めな かったので、同年 7 月に再手術を行った。播種結節を認めず、 CY 0 であることも確認し、膵体尾部切除術 (D 2 郭清) を行った。 病理診断はypT 3 N 1 M 0 Stage II Bであった。補助化学療法と してS 1 を 1 年間内服し、術後 1 年 5 ケ月無再発生存中である。

14 二回の腹燃内再発巣切除と化療により 5 年以上生存中 の膵体部癌の 1 例

春日井市民病院外科

山本泰資、山口竜三、古田美保、渡邀真哉、會津恵司、井原努、 玉井宏明、三輪知弘、有元淳記、榊原昌志、山中美歩、三竹泰弘 進行膵癌術後の腹腔内再発巣の切除が長期生存につながる報告は 少ない。再発切除と化療の併用により長期生存の 1 例を報告する。 症例は68歳男性。胃体部後壁浸潤を伴う膵体部癌に対し、膵体尾 部脾切除、胃部分切除を施行 (stageIVa)。補助化療はS 1 内服。 術後 3 年、CA19- 9 が上昇し、胃再発を認めた。噴門側胃切除、 空腸間置を施行。術後 3 年 6 ケ月、再度マーカーが上昇。肝 S 5 単発転移と複数の微小肺転移と骖断した。GEMを 6 ケ月間投与 すると、肺病変は消失、肝も単発のままであったので $\mathrm{S} 5$ 亜区域 切除を行った。術後 4 年 7 个月、マーカーの再上昇、微小肺転移 を認めた。nab-PTX + GEM 療法により、マーカーは陰転、肺病 変も不明瞭となり、 5 年 3 ケ月現在元気である。
15 自動吻合器を用いたストーマ脱出の術式 藤田保健衛生大学総合消化器外科

升森宏次、前田耕太郎、花井恒一、佐藤美信、小出欣和、松岡 宏、 勝野秀稔、遠藤智美

ストーマに扩ける合併症として、結腸のストーマ脱出はストーマ 合併症のなかでも最も多い合併症で、しばしば治療に難渋する。 今回ステープラによる腸管切除で良好な結果を得ているので報告 する。(1)自動吻合器による切除閉鎖（2 例）：双孔式の場合、肛 門側腸管の減圧が不要な例では、肚門側脱出腸管に対し、できる かぎりひきだし、皮膚に平行にステープラをかけ切除閉鎖。手術 時間は25３5分。(2)自動吻合器による切除吻合 (13例)：双孔式 の場合、肛門側腸管の減圧が必要な時は内腔と外側に縦にステー プラをかけ切離し、観音開きとなったところで、ステープラの断 端部分と皮膚が平行になるようステープラをかけ切離する。手術 時間は $15 \sim 75$ 分。高齢者や全身状態の悪い患者にも短時間で安全 に行える手技であり、有用な術式であると考えられた。

16 Single site laparoscopic cholecystectomyにおける術 野展開の工夫

名古屋大学大学院医学系研究科消化器外科学

末岡 智、藤原道隆、高見秀樹、神田光郎、林 真路、田中千恵、 小林大介、山田 豪、藤井 努、小寺泰弘

【緒言】 Single site laparoscopic cholecystectomy（SSLC）は視 野展開に制限があり工夫を要する。当科のSSLC (+ 1 port) 手 技を報告する。【方法】臍を $Z$ 切開しマルチチャンネルポートを 挿入、右肋弓下に細径ポートを挿入する。最初に直針付きナイロ ン糸で肝円索を吊り上げる。Dome down法で開始し、底部の胆 囊漿膜層の切開を行ったところで、肝臓側切離端を同ナイロン糸 で星引し、最初の毫引糸を合わせた 2 本で肝臓を吊り上げ術野を 展開する。肝床を剥離し CVS 視野としたところで、胆囊管、胆 囊動脈を切離し胆囊切除を完了する。結果】 2 例に同手術を行い、 良好な視野で手術が可能であった。【結語】SSLCの術野展開にお いて、同方法は有用と考えられた。

17 骨盤操作先行ロボット支援腹胿鏡下直腸切除術の経験 豊橋市民病院一般外科

伊藤喜介、相場利貞、加藤岳人、平松和洋、柴田佳久、吉原 基、 青葉太郎、山口直哉、小池佳勇、藤田 健、和田幸也、三品拓也、 神原祐一、西村元伸、小林龍太朗、出井秀幸

当院では2014年11月より da Vinci Siを用いたロボット支援腹腔 鏡下直腸手術を導入し、現在では臨床試験として症例経験を積ん でいる。ロボット使用区分はHybrid法を採用し、左側結腸の授 動操作 (主に外側アプローチ) と、直腸間膜の処理、腸管切離 · 吻合を従来の腹腔鏡操作で行っている。ロボット手術導入期に、 授動したS 状結腸間膜が骨盤内に落ち込み、ロボットによる骨盤 内操作の視野が高度に阻害される経験をしたため、骨盤内操作を 岬角以上の処理に先行して行う方法を導入した。以後、術操作は 円滑となり、現在も本法を継続している。実際の手術手技をビデ オで供覧し、報告する。 
18 「ヘパリフトX」腹腔鏡下手術における安全で簡便な 新しい肝圧排器具

名古屋大学大学院医学系研究科消化器外科学

橋本良二、藤原道隆、田中千恵、神田光郎、小林大介、山田 豪、 中山吾郎、藤井 努、杉本博行、小池聖彦、小寺泰弘 腹臆鏡下胃切除や腹部食道手術において、良好な術野を確保する 目的でNathnson 鈎やペンローズなどを用いた肝臓の吊り上げや 圧排が行われている。しかし術後に肝酵素上昇や時に梗塞が起こ り、安全かつ簡便で、肝臟に対して愛護的に圧排する方法が望ま れている。我々は肝圧排器具へパリフトXを開発し、2011年10月 から現在までに142例に使用した。肝挙上所要時間や術中トラブ ル、術後の肝機能などを評価しその安全性を検討した。平均所要 時間は9.2 4 分、追加手技を要した症例 2 例、術中トラブル 2 例であった。術後 1,2 日目の肝機能は当科で施行した他の手技と 比較して有意に低かった。へパリフトXを供覧し、その使用方法 につき紹介する。

19 腹胿鏡下胃切除術における肝圧排法（PROLENE hanging (PH) 法)

愛知県がんセンター中央病院消化器外科

岩田至紀、三澤一成、伊藤友一、伊藤誠二、小森康司、安部哲也、 千田嘉毅、木村賢哉、木下敬史、植村則久、川上次郎、清水泰博、 木下 平

胃癌手術では肝外側区域の適切な圧排は不可欠である。我々は曲 針付 2-0プロリン糸を用いた肝挙上方法 (PROLENE hanging (PH）法）を考案し行っている。腹腔内に入れた曲針付プロリン 系を左横隔膜下面の腹膜、食道裂孔右側の横隔膜下腹膜、および 右横隔膜下腹膜の計 3 力所に通す。左上腹部腹壁を通してプロリ ン糸両端を体外に誘導、肝外側区域を圧排する。胃癌患者101例 にPH法を用い腹腔鏡下胃切除術を施行した。術中に他の圧排方 法を追加した症例はなく、肝臓損傷もなかった。左副肝動脈切離 症例を除く77例のAST/ALT（平均值）はそれぞれ術前 $22.4 / 21.5$ 、術後 1 日目57.0/53.7、3 日目25.5/36.5で、術後 1 日目 に上昇するものの術後 3 日目にはほほ正常範囲まで改善してい た。

PH法は、低コストで簡便、安全に施行できる有用な肝挙上法で ある。

\section{0}

鼠径ヘルニア術後難治性漿液腫に対し切除術を行った 一例 小牧市民病院外科

伊藤俊成、佐藤雄介、植村友稔、田中健士郎、笹原正宽、上嶋 三千年、鈴木雄之典、長谷川和也、間下優子、田中恵理、井戸田 愛、村上弘城、神浐章之、横山裕之、望月能成、谷口健次、末 永裕之

症例は53歳男性。25年前からの左鼠径部の膨隆を主訴に当科受診。 左外鼠径へルニアの診断にて鼠径ヘルニア根治術 (Mesh plug 法) を行った。術後 2 日目に退院となったが、術後 1 週間後より左陰 囊基部の腫脹を自覚。術後漿液腫と診断し数度穿刺ドレナージを 行ったがすぐに貯留した。術後 6 か月目でも腫瘤は残存。持続ド レナージを行ったが、排液が続き腫瘤の縮小はみられず。治療希 望も強く難治性漿液腫として腫瘤切除をおこなった。手術では腫 瘍壁を可及的に切除し、剥離断端を縫合し浸出液の漏出を防止し た。その後 2 ケ月経過するが漿液腫の再発は認めていない。鼠径 ヘルニア術後の漿液腫の多くは自然吸収され長期に残存すること
は少ない。難治性の漿液腫に対し切除術を行った 1 例を経験した ので報告する。

\section{1 鼠径部嵌頓ヘルニアに施行した TAPP法17例の検討} 刈谷豊田総合病院外科

早川俊輔、早川哲史、近藤靖浩、野々山敬介、渡部かをり、藤幡 士郎、宮井博隆、安田 顕、山本 稔、北上英彦、清水保延、田 中守嗣

当科では2006年 4 月から 2014 年 3 月までに80例の鼠径部嵌頓へル ニアに対する緊急手術を経験し、うち17例にTransabdominal preperitoneal approach 法 (以下 TAPP法) を施行した。手術成 績を検討し、本症に対するTAPP法の有用性を検討する。患者 平均年齢は71.1歳、男女比 $10 ： 7$ 、腸管切除施行症例は 3 例であ った。平均手術時間は135分、出血量（中央值） $5 \mathrm{ml}$ 、術後平均 在院日数は 6 日であった。重篤な合併症として手術との関連は不 明だが、退院後に重篤な誤嬩性肺炎にて死亡した症例を 1 例、術 後 1 か月に遅発性の小腸穿孔を発症し、再手術が必要であった症 例を 1 例認めた。鼠径部嵌頓へルニアに対する TAPP法は術後 在院日数短縮など $\mathrm{QOL}$ の向上に寄与できる可能性があるが、腸 管の観察時に配慮が必要と考えられた。

22 Amyand's hernia類似の鼠径ヘルニアの 1 例

公立陶生病院外科

清水三矢、杉山史剛、林 正吾、吉田光一、友杉俊英、荘加道太、 澤木康一、日比野壮貴、松下英信、高橋卓嗣、大河内治、川瀨義 久

症例は61歳男性。右巣径部腫脹、右下腹部から鼠径部の痛みを主 訴に受診。立位で明らかとなり臥位で消失する右鼠径部膨隆を認 め、身体所見のみで右奧径へルニアと術前診断し、腹腔鏡下奧径 ヘルニア修復術を予定した。術中所見では、右内外単径ヘルニア を認めたが、内鼠径輪の下端に腫大した虫垂と虫垂間膜が癒着し ており虫垂炎の所見も認めた。ヘルニア内容の一部が虫垂炎とな っている虫垂であり、Amyand's hernia類似の単径ヘルニアと考 えられた。最終的な術式は腹腔鏡下虫垂切除術と鼠径部切開 $\mathrm{Bi}-$ layer法による鼠径ヘルニア根治術とした。Amyand's herniaと は、虫垂がヘルニア内容となりその虫垂が嵌頓した鼠径ヘルニア で非常に稀な疾患である。今回我々は術中所見で診断したAmyand's hernia類似の営径ヘルニアを経験したため、若干の文献的 考察を加えて報告する。

\section{3 上腰ヘルニアの一例}

豊橋市民病院一般外科

西村元伸、平松和洋、加藤岳人、柴田佳久、吉原 基、青葉太郎、 相場利貞、山口直哉、小池佳勇、藤田 建、和田幸也、三品拓也、 伊藤喜介、神原祐一、小林龍太朗、出井秀幸

【症例】49歳男性。1 年ほど前から右側腰背部の痛みを自覚。近 医受診し腹部CTにて腹壁ヘルニアを疑われ当科紹介受診。しか し身体所見上、同部位の澎隆を認めず、息んでも変化はなかった。 脂肪腫と診断し経過観察方針とした。1 週間後痛みが続くため当 科再診。エコーにて上腰三角にヘルニア門と同部位より脱出する 低エコー域を認め上腰ヘルニアと診断し、手術を施行した。全身 麻酔下、腹臥位にてヘルニア門の直上で約 $10 \mathrm{~cm}$ の皮膚割線に沿 った皮切とした。ヘルニア門にMesh-plugを挿入し、その上を onlay patchで覆った。術後経過は良好で術後 2 日目に退院とな った。 
【考察】腰背部に脂肪成分を主とした腫瘤を認めた場合、腰へル ニアも鑑別に挙がる。また、身体所見上腫瘤を認めない時は、エ コーにてヘルニア門を確認することが鑑別する上で有用であっ た。

\section{4 傍十二指腸ヘルニアの 1 例}

県立多治見病院外科

根木隆浩、梶川真樹、小西 滋、野村尚弘、浅田崇洋、鎗田哲暢、 田中伸孟、山中雅也、岡野佳奈、伊藤雄貴、原田明生

症例は59歳男性。開腹歴なし。2 日前からの腹痛を主訴に近医受 診。CTで絞扼性イレウスを疑われ当院に転院搬送された。腹部 は左側が優位に膨隆しており、同部位に圧痛を認めた。造影 CT では拡張した小腸が左上腹部に集簇しており内へルニアによる絞 扼性イレウスを疑い緊急手術を施行した。下腸間膜静脈の左背側 へ拡がる左傍十二指腸ヘルニアを認め大部分の小腸が陥頓してい た。小腸を環納すると腸管の色調は改善したため腸切除は行わず、 ヘルニア門を縫合閉鎖して手術を終了した。術後経過は良好で第 12病日に退院、その後再発は認めていない。本症例について文献 的考察を加えて報告する。

\section{5 肝外門脈閉塞症を合併した胆囊皮膚瘦の 1 例} 公立陶生病院外科

澤木康一、林 生吾、杉山史剛、吉田光一、清水三矢、友杉俊英、 荘加道太、日比野壯貴、松下英信、高橋卓嗣、大河内治、川瀬義久 症例は 82 歳、女性。一週間前からの右季肋部の有痛性腫瘤を主訴 に受診、CTにて右側腹壁に軟部腫瘤を認めた。胆囊は萎縮して いたが腫瘤と近接していた。その際に、肝外門脈閉塞症を認めた。 腹壁膿瘍や軟部腫瘤を考慮し皮膚科にて生検を施行された。生検 14日後の通院日に疼痛の増悪と貧血の進行を認めたため入院精查 とした。入院日の翌日に生検部から排膿を認め開放としてドレナ ージ治療を継続したところ、腫瘤は縮小し疼痛はほぼ消失した。 瘦孔造影を行い胆囊内への流入を認め、胆囊皮膚瘦と診断した。 入院 29 病日に開腹にて胆囊摘出術を施行した。胆囊は硬く周囲と 癒着しており腹壁・横行結腸の合併切除を要した。病理検査では 悪性所見は認めず、胆石性胆囊炎に伴う胆囊皮膚瘦と診断した。 比較的まれな胆囊皮膚瘦の 1 例を経験したので若干の文献学的考 察を行い報告する。

\section{6 緊急開腹胆囊摘出術を施行した胆囊捻転の 2 例}

\section{大垣市民病院外科}

仲野 聡、金岡祐次、原田 徹、龟井桂太郎、前田敦行、高山祐 一、深見保之、尾上俊介、大塚新平、森 治樹、渡邊夕樹、堀米 香世子、吉川晃士朗、寺崎史浩、三岡裕貴

症例 $1: 82$ 歳女性でBMI17。主訴は右季肋部痛。採血検查で $\mathrm{WBC} 25,510 、 \mathrm{CRP} 23.32 \mathrm{mg} / \mathrm{dl}$ 、腹部造影 CT 検查で胆囊壁の造影 不良と胆囊管の捻転を認め、胆囊捻転の診断で緊急胆囊摘出術施 行した。手術所見で胆囊は $720^{\circ}$ 捻転し、虚血性壊死を呈していた。 手術時間53分、出血量 $10 \mathrm{ml}$ 。病理組織学検査で全層性壊死を認 めた。症例 2 :88歳女性でBMI18。主訴は右季肋部痛。採血検査 で WBC20,280、 CRP $2.57 \mathrm{mg} / \mathrm{dl}$ 、腹部造影 CT 検查で $10 \mathrm{~mm}$ の胆 石と胆囊壁の造影不良を認めた。急性胆囊炎の診断で緊急胆囊摘 出術施行した。手術所見では $360^{\circ}$ 捻転。手術時間 43 分、出血量 $10 \mathrm{ml}$ 。病理組織学検査で粘膜壞死を認めた。共に術後経過良好 で退院した。やせ型高齢女性の急性腹症では胆囊捻転も考慮する 必要がある。
27 腹胿鏡下胆囊摘出術を施行した左側胆囊の 1 例 $\mathrm{JA}$ 愛知厚生連海南病院外科

矢田吉城、石原博雅、一川貴洋、小林大悟、野々坦郁絵、増㴊麻 里子、柴田有宏、出口智宙、高瀬恒信、矢口豊久

症例は84歳女性。突然発症した心窩部痛で当院受診し、CT検査 で胆囊結石、総胆管結石、肝内胆管拡張を認めた。緊急 $\mathrm{ERCP}$ 施行し内視鏡下に総胆管結石を排石した後、腹胿鏡下胆囊摘出術 を施行した。腹腔内を観察すると、胆囊底部が肝円索より左側に 存在し左側胆囊と診断した。安全に手術を進めるために、胆囊底 部から剥離を行い胆囊摘出とした。術中、術後は合併症なく経過 し、術後第 3 病日に退院となった。左側胆囊に対して腹腔鏡下胆 囊摘出術を施行する場合、十分な視野を確保し安全に手術をすす める必要がある。今回我々は左側胆囊の 1 例を経験したので若干 の文献的考察を加え報告する。

28 血清CA19-9 異常高值を伴った胆囊炎の 1 例 西尾市民病院外科

岸田貴喜、市川俊介、濱田琴巳、稲生照久、藤竹信一、上村孝法、 和田応樹、襧宜田政隆

症例は67歳男性。発熱、右季肋部痛を主訴に受診。WBC13,200/ $\mu \mathrm{L} 、 \mathrm{CRP} 34.54 \mathrm{mg} / \mathrm{dL}$ と炎症反応高值を認め、腹部 CT 検查で胆 囊壁肥厚、周囲脂肪織濃度の上昇を認めたため急性胆囊炎の診断 で同日 PTGBD施行後、消化器内科入院となった。入院時血清 CA19- 9 值が $10,342 \mathrm{U} / \mathrm{mL}$ と著明な高值を呈していた。術前の再 検で血清CA19- 9 值は $15.9 \mathrm{U} / \mathrm{mL}$ と正常化しており、画像所見上 も悪性疾患を疑う所見は認めなかったため、血清CA19-9 高值 は胆囊炎によるものと考え、PTGBD 留置後30日目に腹腔鏡下胆 囊摘出術を施行した。切除標本の肉眼所見及び術後病理組織診断 でも悪性所見は認められなかった。血清CA19-9 值は胆囊炎を はじめとする良性疾患においてもしばしば上昇するが、本症例の ように胆囊炎に血清 CA19- 9 值が $10,000 \mathrm{U} / \mathrm{mL}$ 以上の異常高值を 伴うことは比較的稀であるため、若干の文献的考察を加え報告す る。

29 多型慢性痒疹にて発症した胆囊内分泌細胞癌の一例 蒲郡市民病院外科

藤井善章、杉浦元紀、小川 了、佐藤幹則、中村善則 [はじめに ]

胆囊内分泌細胞癌は比較的稀である。今回多型慢性痒疹にて発症 した症例を経験したので報告する。

[症例 ]

症例は67歳男性。平成 27 年 1 月全身掻痒感、皮疹を主訴に当院皮 膚科初診。多型慢性棒疹の診断で治療施行。同時に悪性腫瘍検索 を行った。CT検查で胆囊腫瘍を指摘された。EUSにて胆囊に 3 cmほどの血流のある腫瘤、腹腔内リンパ節腫脹を認めた。また胆 囊壁の層構造は確認できずSS以媣の胆囊癌の診断で当院外科転 科となった。平成 27 年 3 月に拡大胆囊摘出術を施行した。病理結 果はリンパ節転移陽性、肝内直接浸潤、神経浸潤を認める、胆囊 原発内分泌細胞癌であった。セカンドオピニオンも行ったが、本 人の希望で補助化学療法は施行せず、現在外来にて経過観察中で ある。

[まとめ ]

胆囊内分泌細胞癌は比較的まれで悪性度が高く、予後不良である。 若干の文献的考察を加え、考察する。 
1 例

名古屋大学大学院腫瘍外科

宇治誠人、水野隆史、上原圭介、江畑智希、國料俊男、横山幸浩、 角田伸行、菅原 元、伊神 剛、深谷昌秀、山口淳平、宮田一志、 梛野正人

症例は70代の女性。前医で肝腫瘍を指摘されて当院紹介となった。 肝腫瘍は肝左葉及び前区域を占める径 $9.6 \times 8 \mathrm{~cm}$ 大の単発腫瘍 で、同時に下部消化管内視鏡検査で上行結腸に 2 型進行癌を認め た。上行結腸癌同時性肝転移と診断し、XELOX+Bevacizumab 療法を導入した。9コース施行後に肝腫瘍は径 $5 \times 3.5 \mathrm{~cm}$ 大に縮 小し、肝左 3 区域切除を施行し、次いで右半結腸切除を施行した。 病理診断で両者は明らかに異なった組織型を示しており、組織学 的診断から肝腫瘍は肝内胆管癌と診断した。

本症例はXELOX+Bevacizumab 療法の肝内胆管癌に対する有効 性を示唆するものである。

\section{1 胆管腫瘍栓を伴った肝細胞癌の 1 例}

\section{安城更生病院外科}

陸 大輔、平松聖史、佐伯悟三、雨宮 剛、後藤秀成、関崇、 高橋範子、藤枝裕倫、牧田 智、河南晴久、鈴木優美、尾崎友理、 牛田雄太、崔 尚仁、新井利幸

症例は65歳、男性。腹痛を主訴に当院受診し、肝機能異常を認め たため精查した。MDCTでは肝 S 8 に $24 \mathrm{~mm}$ の腫瘍と肝内胆管（B 8 ）の拡張および胆管腫瘍栓を疑う軟部院影を認めた。EOBMRIでも肝 S 8 に $20 \mathrm{~mm}$ の腫瘍と上流側の胆管拡張を認めた。ERC ではB 8 は造影されず、B $5 / 8$ 合流部も狭窄を認めたが右肝管に は異常を認めなかった。胆管腫瘍栓を伴う胆管細胞癌の術前診断 で手術を施行した。術中迅速組織診にて右肝管切離部が偽陽性で あったことから肝右葉切除＋肝外胆管切除再建を施行した。術後 経過良好で、術後22日目に退院した。摘出標本の病理組織学的所 見は胆管内に polipoidに腫瘍が突出する肝細胞癌の診断であっ た。比較的まれな胆管腫瘍栓を伴う肝細胞癌の 1 例について報告 する。

32 約 1 年の経過観察により腫瘍が顕在化した限局性胆管 拡張を伴う肝内胆管癌の 1 例

名古屋大学腫瘍外科

金子博和、江畑智希、横山幸浩、國料俊男、角田伸行、伊神 剛、 菅原 元、深谷昌秀、上原圭介、水野隆史、山口淳平、宮田一志、 梛野正人

症例は65歳男性。肝 S 6 の限局性肝内胆管拡張を認め当院紹介。 肝門部胆管、総胆管から生検を行ったが陰性。ENBDをB 6 に留 置し、6 回胆汁細胞診を提出したがいずれも院性であった。 PETCTでも異常集積を認めず、炎症性胆管狭窄と考え経過観察 となった。その後徐々にCA19- 9 は上昇。腹部CTで肝S 5 / 6 の 腫瘤性病変が顕在化してきたため、初回受診時から11ヶ月後、肝 後区域切除を施行。病理組織学的所見は中分化腺癌であった。肝 内胆管拡張のフォローアップの重要性を改めて認識した一症例を 経験したので報告する。
33 上腸間膜動脈由来の左肝動脈が膵頭部腹側を走行する 破格を伴った十二指腸乳頭部癌の 1 例

春日井市民病院外科

三竹泰弘、山口竜三、古田美保、渡邊真哉、會津恵司、井原 努、 玉井宏明、三輪知弘、有元淳記、榊原昌志、山中美歩、中橋剛一、 山本泰資

症例は75歳男性。健診での膵䣲素上昇が乳頭部癌診断の契機であ った。併存する AR 4 度MR 4 度の高度心臓弁膜症も手術適応て あったが、まず乳頭部癌を治療した（亜全胃温存膵頭十二指腸切 除、手術時間 305 分、出血 $440 \mathrm{~g} 、 \mathrm{POD} 8$ 退院）。本症では右肝動 脈は上腸間膜動脈（SMA）由来で膵背側を走行していた。左肝 動脈（LHA）もSMA由来で第二空腸動脈（J２Ａ） と共通幹を 形成していたが、 $\mathrm{J} 2 \mathrm{~A}$ と分岐後、膵腹側を横断・走行していた。 これを温存するため、LHAをテープで牽引しながら門脈腹側で 膵を切離し、切除膵はLHA 背側をくぐらせた。術後経過は良好 であった。まれだが膵手術に影響する解剖学的破格なので、文献 的考察とともに報告する。

34 大腿静脈内へ急速進展した血栓を伴う大伏在静脈 venous aneurysm $の 1$ 手術例

豊橋市民病院一般外科1、同心臟血管外科 2 、同呼吸器外科 ${ }^{3}$ 神原祐一1、中山雅人 2 、外山正志 2 、親松裕典 ${ }^{3}$

70歳、女性。以前より右大腿の皮下腫瘤を自覚していた。エコー で大伏在静脈（GSV）の血管瘤と瘤内血栓を認めた。1 力月前の CTで後方視的に血栓を確認したが、変化はなかった。初診から 4 日後に待機的手術を行った。手術直前のエコーでは、血栓が大 腿静脈内一約 $2 \mathrm{~cm}$ 進展していた。手術は血栓除去と瘤切除を行っ た。GSVの限局性囊状拡張であったためvenous aneurysm (VA) と診断した。VAは稀な病態であり、部位によっては肺血栓塞栓 症（PE）が続発する。血栓が急速進展する場合もあるため、可 及的早期に手術を行うのが望ましい。待機的手術を行う場合は $\mathrm{PE}$ の予防的治療の考慮と手術直前に血检の進展範囲を再確認し、 柔軟な手術戦略を練る必要がある。

\section{5} 左心房内血栓による大動脈塞栓症に脊䯣梗塞を合併し た一例

JA 愛知厚生連豊田厚生病院外科

池田修太、水野敬輔、久留宮康浩、世古口英、小林 聡、河合清 貴、桐山宗泰、大岩 孝、宮村 径、富永健太、神野孝徳、中島 悠、森万希子、渡辺裕樹

症例は79歳男性。早朝に突然両下肢のしびれと麻痺があり救急搬 送された。既往歴・併存症として心房細動、狭心症、心不全、大 腸癌術後、食道癌化学放射線療法後、MDS白血化、CKDなどが あった。造影CTにて腎動脈下大動脈から両側の大腿動脈にかけ て造影効果なく、急性動脈閉塞と診断した。心房細動について左 心房内血栓を指摘されており、心房内血栓塞栓と考えられた。下 肢の血流障害は高度であったため、緊急で血栓除去術を施行した。 両側大腿動脈を露出して $4 \mathrm{Fr}$ fogaty カテーテルで血栓除去を行 ったところ多量の血栓が回収でき拍動も出現したため終了とし た。術後は両下肢の血流は良好で壊死の所見もなかったが、両下 肢麻痺残存したため脊髄MRI撮影したところ脊䯣梗塞と診断し た。術後に腎機能悪化を認めたが透析導入することなく保存的に 軽快した。現在両下肢麻痺に対してリハビリ中である。

今回心房細動により生じた心房内血栓塞栓で脊䯣梗塞を発症した 症例を経験したため報告する。 
36 腹部藏器虚血を合併した急性 B 型大動脈解離の 1 例 愛知医科大学血管外科 1 、同放射線科 2

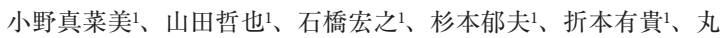
山優貴、石口恒男 ${ }^{2}$

症例は68歳女性。平成 27 年 9 月に突然の腰背部痛で発症し、急性 大動脈解離と診断され転院搬送となった。CT検查で遠位弓部か ら腎動脈レベルまで解離しており、腹腔／上腸間膜動脈 (CA SMA）は造影されなかった。腸管虚血を伴ったB型解離と診断 し緊急手術を施行した。胸部ステントグラフト $\left(\mathrm{CTAG}^{\mathrm{TM}}\right)$ でエ ントリーを閉鎖し真䏶血流を改善したが、CA/SMAは描出され なかった。直ちに開腹してSMA末梢からステント留置 $\left(\mathrm{Epic}^{\mathrm{TM}}\right)$ したところ、腸管／肝血流は回復した。翌日にセカンドルック手 術で壊死した結腸右半を切除した。術後、菌血症や急性循環不全、 腎不全などを呈したが集学的治療により徐々に回復し、術後 3 か 月で転院となった。

\section{7 術後再膨張性肺水腫を合併した自然血気胸の 1 例} 碧南市民病院外科

好中久晶、梶田正文、亀岡伸樹、長野郁夫、金澤英俊、佐藤太一、 松本直基

症例は31歳、男性。前日から持続する右胸部痛と呼吸苦を主訴に 当院内科受診した。来院時レントゲンで右気胸、胸水を認めた。 胸水穿刺を施行したところ血性であったため、自然血気胸と診断 し当科依頼となった。緊急手術が必要と判断し、緊急手術を施行 した。胸腔鏡で観察すると胸腔内は凝血塊を伴う血性胸水を認め、 胸壁に露出血管が存在し出血していた。また肺尖部には囊胞を認 めた。止血を行った後、肺部分切除を施行してドレーンを留置し 手術を終了した。しかし抜管後、ただちに呼吸苦が出現、レント ゲンで再膨張性肺水腫と診断し、再挿管後呼吸器管理とした。肺 水腫は次第に軽快し翌日抜管した。術後再膨張性肺水腫を合併し た自然血気胸の 1 例を経験したので、若干の文献的考察を加えて 報告する。

38 保存的治療が奏功した外傷性多発仮性肺囊胞の 1 例 一宮市立市民病院外科 1 、同呼吸器外科 ${ }^{2}$

高島幹展1、篠塚高宏1、宇佐美範恭2、藤田恵三1、野峷悠太郎1、 中村俊介 ${ }^{1}$ 、宇田裕聡 1 村井俊文 1 、阪井 満1、橋本昌司 1 、永田 二郎1

症例は16歳男性。バイク走行中にトラックと正面衝突し受傷した。 受傷直後の胸部 CT 検查にて両側肺挫傷、皮下気腫および縦隔気 腫さらにニボーを伴う多発空洞性病変を認めた。呼吸不全を認め たため、ERにて気管挿管を施行し、外傷性血気胸に対して、両 側胸腔ドレーンを留置した。外傷性多発仮性肺囊胞と肺胞出血に 対し人工呼吸器管理を中心に集中治療室にて全身管理を施行し た。第 4 病日に外科的気管切開を施行し、徐々に呼吸状態や肺胞 出血の改善を認めた。第 8 病日に人工呼吸器を離脱し、第 12 病日 に気管切開チューブを抜去した。フォローの胸部 CT検査にて肺 囊胞の改善を認めたため、第16病日に自宅退院となった。保存的 治療が奏功した外傷性多発仮性肺囊胞の 1 例を経験したので、若 干の文献的考察を加えて発表する。

\section{9 外傷性右横隔膜損傷の 1 例} 中京病院外科

寺境宏介、小林真一郎、東島由一郎、谷村葉子、伊東悠子、石田 知之、鳥居直矢、堀澤七恵、森山瑞紀、澤崎直規

【症例】28歳男性。【現病歴】軽自動車同士の交通外傷にて救急搬 送。【現症】GCS12点 (E 2 V 4 M 6 )、血圧 $115 / 41 \mathrm{mmHg}$ 、脈拍 $150 \mathrm{bpm} 、 S p O 284 \%$ (room air)、呼吸回数37回/分。【画像所見】 CTにて右多発胁骨骨折、多発骨盤骨折、右横隔膜の著明な拳上 を認めた。USで第 4 肋間から肝臓を確認。【経過】外傷性右横隔 膜損傷の診断にて緊急手術施行。上腹部正中切開にて開腹すると 横隔膜が裂け、肝右葉が胸腔内に脱出していた。腹腔内からの還 納が困難であったため第 7 肋間での開胸を追加し、用手的に還納 した。約 $15 \mathrm{~cm}$ にわたって裂けた横隔膜を縫合閉鎖し手術終了。 肝表面に裂創があったが処置不要であった。術後経過は良好であ り、合併症は認めなかった。肝機能も問題なく、術後 23 日目に転 院となった。まれな症例を経験したため報告する。

\section{0 保存的に治癒しえた特発性気腹症の 1 例} 愛知医科大学病院消化器外科

森 大樹、駒屋憲一、有川 卓、宮地正彦、小松俊一郎、大橋紀 文、石黒成治、安藤景一、齋藤卓也、大澤高陽、松村卓樹、岩田 力、倉橋真太郎、内野大輪、安井講平、井戸美来、佐野 力 腹腔内遊離ガス像は消化管穿孔に伴い、緊急手術を要す可能性が 高い所見である。一方で、消化管穿孔を伴わない腹䏶内遊離ガス 像は特発性気腹症と報告され、保存的治療が選択されることがあ る。

症例は74歳男性。既往歴は高血圧を認めるが腹部手術歴、消化 管潰瘍、頽室症などの既往は認めなかった。腹部膨満感を主訴 に近医受診。腸閉塞の疑いで当院紹介となった。腹部膨満感と 軽度の圧痛を認めるも、発熱なく、筋性防御や反跳痛などの腹膜刺 激症状は認めなかった。腹部CT検查で大量の腹腔内遊離ガス像を 認めた。また、血液検查所見はWBC $6,700 / \mu \mathrm{l} 、 \mathrm{CRP} 4.46 \mathrm{mg} /$ $\mathrm{dl}$ と軽度の炎症反応を認めるのみであった。特発性気腹症と診断 し保存的加療を選択した。入院後は絶食とし、PPIを使用し経 過観察とした。腹垫内遊離ガス像は残存するものの腹部膨満感 は改善。血液検查でも炎症反応増悪なく、入院後 14 日目に経口摄 取を開始した。症状悪化なく経口摂取 3 日後に退院、外来で経過 観察とした。入院から 39 日経過し腹腔内遊離ガスが消失したこと を確認した。

特発性気腹症と診断し、入院後39日間の観察で保存的に軽快した 1 例を経験した。

\section{1 特発性大網出血の 1 例}

八千代病院外科

二村雄介、杢野泰司、小林一郎、松原秀雄、山崎公稔、村田悠記、 栗田大資、尾入保彰、花澤隆明、弥政晋輔

症例は92歳男性。左上腹部〜下腹部痛を主訴に救急搬送された。 腹部単純 CT T゙肝臓周囲、脾臓外側、ダグラス窝に腹水と、胃大 弯側大網部の軽度な炎症像を認め精查目的に入院となった。試験 穿刺を行うと腹水は血性であった。胃内視鏡では出血の原因とな る所見を認めなかった。以上の所見より特発性大網出血が疑われ た。その後、明らかな腹水の増加を認めず、貧血の進行も認めな かったが、再出血の可能性を考え鏡視下に手術を行った。大網に 血腫を伴った部分を認め、その部位を切除し術後経過は良好であ った。特発性大網出血という稀有な症例を経験したため報告する。 
42 小切開創から腹胿内大量洗浄を施行し、腹腔鏡下に人 工肛門を造設し得た直腸癌術後縫合不全の一例

愛知医科大学病院消化器外科

安井講平、石黒成治、小松俊一郎、安藤景一、大澤高陽、佐野 力

臍部小切開創から腹垫内大量洗浄を施行した直腸癌術後縫合不全 の一例を経験したので報告する。症例：60代男性。直腸癌に対し 腹臆鏡下低位前方切除術を施行し、術後縫合不全による沉発性腹 膜炎を発症し緊急手術を施行。腹胿鏡で観察すると広範囲に便污 染を認めた。臍部小切開創にAlexis ${ }^{\circledR}$ ウーンドリトラクターSを 挿入。臍部創をつり上げ、 1 回で約 $3 \mathrm{~L}$ 洗浄可能で、約 15 分の短 時間で腹腔内を大量洗浄しえた。洗浄が十分であることを腹腔鏡 で確認し、臍部創を用いて回腸人工肛門を造設した。術後 3 日目 から経口摂取を開始、術後35日目に退院した。ウーンドリトラク ターを用いた洗浄ドレナージは、短時間に大量の洗浄を行うこと ができ、洗浄の効果は開腹術に遜色ないものと思われた。

43

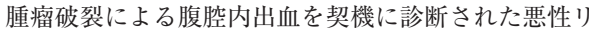
ンパ腫の一例

JA 愛知厚生連豊田厚生病院外科

森万希子、久留宮康浩、世古口英、小林 聡、河合清貴、桐山宗 泰、大岩 孝、宮村 径、冨永健太、神野孝徳、中島 悠、池田 脩太、渡邊裕樹

症例は58歳男性で、左前頭側頭葉神経膠腫切除後の化学療法中に 著明な腹部膨満と腹痛を主訴に受診した。腹部造影 CT で出血を 示唆する腹水の貯留および腸間膜内に $11 \times 18 \mathrm{~cm}$ の単発腫瘤を認 め、腫瘤破裂による腹胿内出血の診断で緊急手術を施行した。開 腹所見では多量の血性腹水と腫瘤被膜の裂隙および腫瘤内部の血. 腫とを認めた。CT上、腫瘤内を上腸間膜動静脈が貫通していた ため切除は不可能と判断し、血腫の除去と出血部位の縫合止血抒 よび診断目的の生検を行った。腫瘤からの oozingが続いたが、 腫瘤内の血腫を除去することにより被膜の縫合閉鎖が可能となり 圧迫止血しえた。病理結果はびまん性大細胞型 B細胞性リンパ腫 であり、現在CHOP療法中である。単発性にリンパ腫大し腹腔 内出血をきたした悪性リンパ腫の一例を経験したので報告する。

\section{4 肺癌大腸転移で緊急手術に至った 1 例}

\section{名古屋掖済会病院外科}

前田周良、河野 弘、木村充志、米山文彦、木村桂子、芥川篤史、 尾辻英彦、明石久美子、清板和昭、長谷部圭史、長尾拓哉、福岡 恵、荣原聖実、萩原康友

症例は80歳男性。肺扁平上皮癌術後再発（局所、縦隔リンパ節、 右大腿部皮膚転移) を認め呼吸器内科通院中、腹痛、食欲低下を 主訴に外来受診し、腹部単純 CT 検査にて、上行結腸に腫瘤性病 変と口側腸管の拡張、微少穿孔を疑う所見を認め、緊急開腹手術 を施行した。上行結腸に全周性腫瘤を触知し前壁側に穿孔部位を 確認した。右半結腸切除術、洗浄ドレナージ術を施行し手術終了 とした。術後 4 日目に食事開始したが、6 日目にドレーンの混濁 を認め縫合不全を惹起、全身状態悪化し術後21日目に死亡した。 摘出標本で得られた病理結果にて肺扁平上皮癌の大腸転移と診断 した。

肺癌の遠隔転移として胃、小腸、大腸など消化管への転移は稀と されている。その中でも大腸への転移はさらに稀であり、本邦肺 癌剖検例 1,775 症例中、 $2.3 \%$ と報告されている。さらに生前に診 断されることは $0.4 \%$ と非常に稀である。また、肺癌大腸転移が
診断された時点で原疾患の進行は著しく、予後も不良である。今 回我々は本症例を経験し肺癌大腸転移につき若干の文献的考察を 加え検討する。

例

愛知県がんセンター中央病院消化器外科

大内 晶、小森康司、木村賢哉、木下敬史、伊藤誠二、安部哲也、 千田嘉毅、三澤一成、伊藤友一、植村則久、夏目誠治、川上次郎、 清水泰博

症例は77歳、女性、 2 年 8 か月前に前医で盲腸癌（tub 2, se, ly $2, \mathrm{v} 1, \mathrm{n} 1 （ 2 / 7)$, pStageIIIa）に対して腹䏶鏡下回盲部 切除術を施行後、定期検查で右横隔膜腫瘍を認め当科紹介となっ た。CT、USで肝 S 4 頭側の横隔膜に $2 \mathrm{~cm}$ 大の腫瘤を認め、 PET-CTで同部位にFDGの集積を認めた。以上より盲腸癌術後、 孤立性腹膜播種再発と診断して手術を施行した。開腹すると右横 隔膜に $2 \mathrm{~cm}$ 大の腹膜播種を認め、横隔膜部分切除を行い腫瘍を 摘出した。病理は前回の組織像に類似した中分化腺癌で、盲腸癌 の腹膜播種再発と診断した。結腸癌術後の孤立性腹膜播種再発は 頻度は比較的少なく、 R 0 切除で良好な成績が得られるため積極 的な外科的切除が推奨される。若干の文献的考察を加えて報告す る。

46 大腸癌術後補助化学療法としてのUFT/LV 療法中に 多発小腸潰瘍をきたした一例

$\mathrm{JA}$ 愛知厚生連江南厚生病院外科1、同病理診断科2、同薬剂部3、 同外来化学療法センター 4

中村正典1、間下直樹 1 、石榑 清1 、飛永純一1、山村和生 ${ }^{1}$ 、浅井 泰行 1 、呂 成九 1 、斎藤悠文 1 、野々坦彰1、福山隆一 2 、藤井知郎3、 宇根底亜希子 4

症例は79歳女性で、盲腸癌に対して回盲部切除術およびD 3 リン パ節郭清術を行った。fStage III aのため術後補助化学療法として $\mathrm{UFT} / \mathrm{LV}$ 療法（5 日間投与 2 日間休薬）を開始した。内服開始 40日目より下痢（Grade 1) が出現しはじめた。内服開始52日目 に下部消化管出血（Grade 3 ) となり緊急入院となった。同日の 下部消化管内視鏡検查で、吻合部の口側回腸に粘膜の発赤および 不整形の多発潰瘍形成を認めた。化学療法による腸管粘膜障害、 もしくは細菌性腸炎、サイトメガロウイルス腸炎の可能性を考え、 抗生剤や抗ウイルス薬投与を開始した。治療開始日 2 日目に血便 が消失し、14日目に下痢が軽快した。病理組織学的検查や細菌培 養検查、ウイルス学的検査ではいずれも有意な所見なく、化学療 法による多発小腸潰瘍と診断した。若干の文献的考察を加えて報 告する。

\section{7 盲腸捻転の 1 例}

安城更生病院外科

西野翔吾、河南晴久、平松聖史、佐伯悟三、雨宮剛、後藤秀成、 関崇、高橋範子、陸 大輔、藤枝裕倫、牧田 智、鈴木優美、 牛田雄太、尾崎友理、崔 尚仁、新井利幸

症例は54歳、女性。腹痛を主訴に前医を受診。腸閉塞の診断にて 当院転院となった。手術既往はなかった。腹部XPにて、ニボー 形成を伴う腸管の拡張像を認めた。CT上、腸管の著明な拡張と 捻転を示唆する腸間膜血管の渦巻き様の所見を認め、腸管の捻転 が疑われた。下部消化管内視鏡検查を施行すると上行結腸は閉塞 しファイバーの通過は困難であった。以上より盲腸捻転と診断し、 
内視鏡的整復が困難なため同日緊急手術を施行した。開腹すると 盲腸の捻転を認めこれを解除した。捻転した腸管は、穿孔を認め なかったが色調不良であったため、回盲部切除術を施行した。術 後経過は概ね良好で術後第10病日軽快退院した。文献的考察を加 え報告する。

\section{8 骨形成をともなった直腸癌の一例}

名古屋第一赤十字病院一般消化器外科

清水大輔、湯浅典博、竹内英司、後藤康友、三宅秀夫、永井英雅、 吉岡裕一郎、奥野正隆、細井敬泰、南 貴之、加藤哲朗、加藤翔 子、前田真吾、毛利康一、浅井真理子、深田浩志、宮田完志 症例は60歳男性、2014年12月に下痢・血便を主訴に来院し、下部 消化管内視鏡検查で直腸に灰白色の壊死を伴なう結節状の隆起型 腫瘍を認め、生検で腺癌と診断された。CTではRsに隆起型腫瘍 を認めその内部に散在性の点状高吸収域を認めた。Rs, Type 1, SS, N 1， cStage IIIa と診断し低位前方切除術を施行した。摘出 標本の肉眼所見では直腸に $100 \times 80 \mathrm{~mm}$ の多結節状隆起型腫瘍を 認め、病理組織学的に腫大した核を有する異型高円柱上皮細胞が 乳頭腺管構造を形成し増生しており、中分化型腺癌と診断された が、腫瘍の周囲の間質には骨形成を散在性に多数認めた。

\section{S 状結腸癌再発により子宮留膿腫を発症した一例 中部労災病院外科}

高橋秋香、坂口憲史、橋本瑞生、水谷哲之、佐藤文哉、鈴木俊裕、 金原香織、竹林三喜子、藤原 玄

症例は64歳女性。X年、 $\mathrm{S}$ 状結腸癌で $\mathrm{S}$ 状結腸切除を施行した。 術後、化学療法や再発巣切除を繰り返していた。 X+4 年に直腸 $\mathrm{Rb}$ 左壁に再発をみとめた。 $\mathrm{X}+6$ 年にダグラス窩〜左骨盤底に $8 \times 4 \mathrm{~cm}$ の隔壁を伴う液体貯留を認め、卵巣転移と考えた。徐々 に増大し、 $\mathrm{X}+7$ 年には $14 \times 10 \mathrm{~cm}$ まで増大した。この時点で、 直腸左壁の癌は増大し、直腸通過障害を生じ、脆に高度に浸潤し ていた。その頃、 $40^{\circ} \mathrm{C}$ の発熱あり、囊胞性腫瘤内に大量の Air 像 が出現。癌浸潤のある直腸と交通したと考えた。安全に穿刺でき るルートがなかったため、開腹ドレナージを施行した。卵巣転移 腫瘤と考えていたのは子宮で、内部に多量の膿性貯留液を認めた。 便汁ではなかった。臸内は外から浸潤してきた癌で充満し、内腔 は閉塞していた。子宮内部に経腹的ドレーンを留置した。胚の癌 閉塞による子宮留水腫、その感染による留膿腫と診断した。

50 S 状結腸膀胱瘻に対して腹腔鏡下手術を施行した 1 例 名古屋市立東部医療センター外科

江口祐輝、森洋一郎

症例は89歳女性。繰り返す膀胱炎、気尿を主訴に初診となった。 採血上明らかな異常所見は認めず、CT 検查では膀胱内の気腫と ともにS状結腸と連続する管腔構造を認めた。膀胱鏡検查では同 部に発赤粘膜を認めたが、大腸内視鏡検查では有意な所見は認め ず、造影検査でも明らかなリークは認めなかった。しかし総合的 にS 状結腸膀胱瘦と䛦断し、腹膜炎や卵巣摘出など 4 度にわたる 手術歴があったが、腹腔鏡下手術を施行した。術中、S 状結腸と 膀胱との間には瘦孔を認め、S 状結腸膀胱瘦の確定診断を得た。 膀胱の欠損孔は縫合閉鎖し、S 状結腸の瘻孔部は楔状切除した。 本疾患に打ける腹腔鏡下手術は患者に対する負担も軽く、早期の 社会復帰が可能な有効な手段と考えられた。

\section{1 発症機転の異なる小腸リンパ腫の 2 例} 安城更生病院外科

河南晴久、平松聖史、佐伯悟三、雨宮 剛、後藤秀成、関崇、 高橋範子、陸 大輔、藤枝裕倫、牧田 智、鈴木優美、牛田雄太、 尾崎友理、崔 尚仁、新井利幸

小腸リンパ腫の術前診断は難しく、消化管出血、腸閉塞、穿孔等 で発症し緊急手術となることも多い。最近、発症機転の異なる小 腸リンパ腫を 2 例経験したので報告する。症例 1 ：主訴は左下腹 部痛、CT 上free airを認め、穿孔性腹膜炎と診断し緊急手術を 施行した。症例 2 : 主訴は右側腹部痛、CT上回盲部腫瘤と口側 小腸の拡張像を認め、腫瘍による腸閉塞と診断し手術を施行した。 いずれも小腸腫瘍と術中診断し小腸部分切除術を施行した。いず れも病理組織学的診断は小腸リンパ腫 (DLBCL) であった。腸 閉塞で発症した症例 2 は、播種性病変を伴う進行症例で不良な転 帰であった。発症機転の異なる 2 例を対比しながら文献的考察を 加え報告する。

52 急性虫垂炎で発症した虫垂子宮内膜症の 1 例 掛川市・袋井市病院企業団立中東遠総合医療センター外科 豊田良鎬、京兼隆典、河合 徹、渡邊克隆、小出史彦、落合洋介、 浅井悠一、久世真悟

症例は48歳女性。右下腹部痛を主訴に当科を受診した。血液検查 所見では白血球数7,200、CRP:2.64と炎症反応の上昇は軽度であ ったが、腹部造影 $\mathrm{CT}$ 検査では回盲部付近に壁肥厚を伴う虫垂を 認め、その背側に径 $1.5 \mathrm{~cm}$ の内部に低吸収域を有する腫瘤を認め た。急性虫垂炎および虫垂周囲膿瘍形成の診断で緊急腹腔鏡下虫 垂切除術を行った。術中所見は虫垂先端に暗赤色の付着物を認め その周囲には粘液が取り巻いていた。術後経過は良好であり当院 クリニカルパスに準じて術後第 3 病日に退院となった。病理組織 学的検查の結果、虫垂壁外の粘液の漏出を認める部位から子宮内 膜組織を認め、異所性子宮内膜症に伴う急性虫垂炎と診断した。 まれな症例と考えられたため文献的考察を加え報告する。

\section{3 回腸重複腸管の 1 例}

八千代病院外科

花澤隆明、杢野泰司、小林一郎、松原秀雄、山崎公稔、村田悠記、 栗田大資、尾入保彰、弥政晋輔

44歳男性。上腹部痛を主訴に救急外来を受診した。来院時、臍部 に圧痛を認めたが筋性防御は認めなかった。血液検查ではWBC 10,200/ $\mu \mathrm{l} 、 \mathrm{CRP} 0.48 \mathrm{mg} / \mathrm{d} \ell$ あ゙った。腹部CTで鄎室を伴う小 腸壁肥厚と周囲脂肪織濃度の上昇を認めた。メッケル悡室炎の疑 いで抗生剂治療を行い、改善後に再燃予防のため手術を行った。 臍の小切開創から単孔式用開創器を装着し、腹腔鏡下に病変部を 同定した。創外で確認すると隣接する腸管と連続する腸間膜を有 しており、重複腸管と考えられた。腸間膜を切離し、重複腸管の 切除を行った。今回、メッケル喤室炎の術前診断で手術を施行し た重複腸管の 1 例を経験したので、若干の文献的考察を加えて報 告する。 
54 鼠径ヘルニア嵌頓術後にMeckel㮩室による吻合部通 過障害を生じた 1 例

名古屋掖済会病院外科

福岡 恵、河野 弘、木村充志、米山文彦、木村桂子、芥川篤史、 尾辻英彦、明石久美子、清板和昭、長尾拓哉、前田周良、菜原聖 実、萩原康友

症例は 67 歳、男性。1 ケ月程前より右鼠径部の膨隆を自覚するも 自然還納していた。平成 27 年 10 月下旬、昼よりの右鼠径部痛と嘔 気を認めたため、夕方当院を受診した。受診時、右鼠径部に手拳 大の膨隆と硬結、圧痛を認めた。腹部造影 CTではヘルニア内に 小腸の脱出と腹水を認め、口側腸管の拡張を認めた。以上より鼠 径ヘルニア嵌頓と診断して鼠径法にて緊急手術を施行した。術中 所見では $7 \mathrm{~cm}$ の小腸が嵌頓し壞死していた。小腸を引き出す際 に多少の抵抗を認めたが、鼠径法にて小腸部分切除ならびにへル ニア根治術を施行しえた。術後 3 日目にイレウスとなり、吻合部 狭窄疑いにてイレウス管による保存治療を継続したが、改善乏し く審查腹腔鏡を行った。再手術所見では、吻合部口側は拡張して おり、吻合部の肛門側に拡張したMeckel顖室を認めた。吻合部 狭俟もしくはMeckel悡室により吻合部に捻れを生じたと判断し て、吻合部抢よびMeckel悡室を含む小腸を切除した。術後経過 は良好であり、再手術後第11日目に退院した。今回われわれは、 鼠径ヘルニア嵌頓術後にMeckel息室による吻合部通過障害を生 じた 1 例を経験したため、若干の文献的考察を加えて報告する。

55

単孔式腹腔鏡手術を施行した内翻したMeckel憩室に よる腸重積の 1 例

名古屋記念病院外科

宇野泰朗、真田祥太郎、大屋久晴、福岡伴樹、越川克己、佐野正 明

症例は15歳男性、1 週間前からの軽い腹痛を主訴に受診。腹部 CT 検查にて小腸の腸重積を認め、先進部に壁が造影される管腔 を認めMeckel悡室が疑われた。イレウス症状はなく、入院 4 日 目に単孔式腹腔鏡手術を施行した。回腸末端より $100 \mathrm{~cm}$ の回腸に 重積を認め、整復すると先進部に $5 \mathrm{~cm}$ 大の憩室を確認し、榎室 切除を施行した。病理学的検查では胃底腺組織が認められ、 Meckel唕室に矛盾しない所見であった。Meckel喤室が原因の腸 重積症は比較的稀な疾患である。今回、単孔式腹腔鏡手術を施行 した内翻したMeckel憩室による腸重積の 1 例を経験したので文 献的考察も含め報告する。

\section{6}

黒色便を契機に診断された空腸脂肪腫による腸重積症

の 1 例

愛知医科大学卒後臨床研修センター1、同消化器外科 ${ }^{2}$

内原夕貴 1 、宮地正彦 2 、井戸未来2、安井講平 2 、内野大倫 ${ }^{2} 、$ 森 大樹2、倉橋真太郎2 2 大澤高陽 2 、松村卓樹 2 、駒屋憲一2、齊藤卓也2 2 安藤景一 2 、石黒成治 ${ }^{2}$ 、大橋紀文 ${ }^{2}$ 、有川 卓 2 、小松俊一郎 2 、佐 野 力 $^{2}$

症例は72歳、女性。黒色便を主訴に近医を受診した。便潜血検查 陽性で精查加療目的で当院紹介受診した。初診時の血液生化学検 查所見では Hgb $8.4(\mathrm{~g} / \mathrm{dl})$ と貧血を認めた。腫瘍マーカーは CEA $1.6(\mathrm{ng} / \mathrm{mL}) 、 C A 19-93(\mathrm{U} / \mathrm{mL})$ と異常は認めなかった。 腹部造影 $\mathrm{CT}$ 検查所見では空腸に腸重積を認め、肍門側に脂肪腫 を疑う先進部を認めた。小腸内視鏡検査所見ではTreitz 靶帯す ぐ肛門側に長径 $8 \mathrm{~cm}$ ぼの粘膜下腫瘍を認めた。下部消化管内視 鏡検査では数個の腺腫を認めEMRを施行した。以上より空腸脂
肪腫疑いに対して開腹下小腸部分切除術を施行した。開腹時、腫 瘍を先進部として空腸は重積していた。Treitz鞎帯より $30 \mathrm{~cm}$ に腫 瘍を認め小腸を部分切除した。手術時間は73分、出血量は $15 \mathrm{~g}$ 、 術後経過は良好であり術後 7 日目に退院となった。病理組織学的 検查所見では粘膜下に境界明瞭な脂肪集塊を認め小腸脂肪腫の診 断であった。黒色便を契機に診断された空腸脂肪腫による腸重積 症の 1 例を経験したため若干の文献的考察を加え報告する。

\section{7 イレウス管が誘因と考えられた腸重積の 1 例} 豊橋市民病院一般外科

野中有紀子、神原祐一、加藤岳人、平松和洋、吉原 基、柴田佳 久、青葉太郎、相場利貞、山口直哉、小池佳勇、藤田 建、和田 幸也、三品拓也、伊藤喜介、西村元伸、小林龍太朗、出井秀幸 症例は83歳女性。潰瘍により胃切除術の既往がある。腹痛を主訴 に近医を受診し、CTにて癒着性イレウスの診断で、当院紹介と なった。イレウス管を挿入し保存的加療を行ったが、第 3 病日に、 腹痛が増悪しイレウス管から血性排液をみとめた。エコー・CT の所見から腸重積と診断し腸管の循環障害が疑われたため、開腹 手術を施行した。術中、トライツから $40 \mathrm{~cm}$ の空腸に重積を認めた。 Hutchinson 手技を施行したが腸管の色調悪く、腸管切除を施行 した。腫瘍性病変は認めず、イレウス管が誘因と考えられた。術 後経過は良好だった。イレウス管が誘因となった腸重積は比較的 稀であり、若干の文献的考察もふまえ報告する。

58 結腸全摘・回腸切除を要した糞便性イレウスの 1 例 豊川市民病院外科

西土 徹、柴田孝弥、篠田憲幸、齋藤正樹、原田真之資、青山佳 永、牛込 創、堅田武保、彦坂 雄、三田圭子、寺西 太、柄松 章司、西田 勉、佐々木信義

症例は 60 代女性。激しい腹痛と便秘を主訴に救急搬送された。腹 部は全体に膨満していたが腹膜刺激兆候はなかった。腹部 CT 検 查ではS 状結腸から直腸に便塊が存在し、口側の腸管拡張を認め た。糞便性イレウスと䛦断し入院となったが、徐々に全身状態覀 化し入院翌日にショック状態となった。内視鏡的に治療を試みる も不可能であったため、緊急手術を施行した。術中所見では全結 腸および回腸にほぼ連続する虚血性壊死を認めた。宿便による閉 塞性大腸炎から腸管壊死をきたしたと診断し、結腸全摘・回腸切 除・小腸ストーマ造設術を施行した。宿便を契機とした閉塞性大 腸炎で結腸全摘を施行した例は稀であるため、若干の文献的考察 を加え報告する。

59 腸閉塞をきたした回腸子宮内膜症の 1 例 安城更生病院外科

崔 尚仁、平松聖史、佐伯悟三、雨宮 剛、後藤秀成、関崇、 高橋範子、陸 大輔、藤枝裕倫、牧田 智、河南晴久、鈴木優美、 牛田雄太、尾崎友理、新井利幸

症例は 47 歳、女性。卵巣腫瘍の手術既往があった。腹痛を主訴に 当院を受診、術後癒着性イレウスの診断で入院、保存的治療にて 軽快した。退院 7 日後にイレウスが再燃し再入院となった。イレ ウス管による保存的治療で改善が得られず、手術を施行した。開 腹すると、回腸末端より約 $20 \mathrm{~cm}$ 口側回腸が腫瘤状に一塊となっ ていた。瘉着剥離なため同部位の部分切除術を施行した。切除標 本の病理組織学的診断は子宮内膜症であった。腸管子宮内膜症は 比較的まれな疾患であり文献的考察を加えて検討する。 
60

偶発的に発見された成人仙骨前部Dermoid cystの 1

例

大垣市民病院外科

三岡裕貴、金岡祐次、龟井桂太郎、前田敦行、高山祐一、深見保 之、尾上俊介、大塚新平、森 治樹、堀米香世子、渡邊夕樹、寺 崎史浩、吉川晃士朗、仲野 聡、原田 徹

症例は40歳女性。既往歴は腎孟腎炎。腎孟腎炎精查時の腹部造影 CT 検查で仙骨前部に $96 \times 49 \mathrm{~mm}$ の低濃度で造影効果を認めない 囊胞性病変が発見された。MRI検查では辺縁平滑、内部は不均 一で隔壁、被膜様構造を認め陳旧性血腫、髄膜腫、Dermoid cyst、Tailgut cystが示唆された。その他の検查で異常所見はなく、 Dermoid cystの疑いで経仙骨的摘出術を行った。手術所見では 尾骨と腫瘍は離れており Tailgut cystは否定的であった。尾骨と 仙骨の一部は視野を確保するために腫瘍と共に切除した。摘出腫 瘍は $7 \times 5 \times 5 \mathrm{~cm}$ で充実性であった。病理組織学的診断は重層扁 平上皮で覆われた囊胞性病変で、上皮下は平滑筋線維を含む線維 性結合組織で、Dermoid cystであった。成人に扔ける Dermoid cystは比較的稀である。

\section{1 腹些鏡下手術で切除しえた巨大副腎囊胞の一例}

藤田保健衛生大学肝脾外科

三井哲史、加藤悠太郎、过昭一郎、所隆昌、棚橋義直、香川 幹、 杉岡 篤

症例は42歳の女性。右上腹部膨満感を主訴に近医を受診し、右肋 骨部から下腹部までの巨大な腹部腫瘤を触知したため、当院内科 に紹介受診となった。US、CTにて肝下面に内部が均一で低吸収 を示す、 $150 \mathrm{~mm}$ 大の単発性囊胞病変を指摘され、単発性肝囊胞 と診断された。腎臟には囊胞を認めなかった。経過観察をしてい たが、自覚症状が強く、右水腎症も認めたため外科紹介となり、 腹䏶鏡下肝囊胞開空術を予定した。術中所見として、腫崵は肝臓 と連続しておらず、後腹膜に存在したため腹沿鏡下後腹膜腫瘍摘 出術に術式を変更した。腫瑒は右腎臟を正中の左にまで圧排して いたが連続性はなく、卵巣、尿管、腸管からも剥離可能であった が、右副腎の一部が腫掦の壁に強固に癒着していたため、右副腎 を一部合併切除した。病理所見は副腎由来血管性囊胞であった。 巨大副腎囊胞はまれであり、後腹膜囊胞の腹胿鏡下手術例もあま り報告がないため、ここに報告致します。

\section{2} 大網原発孤立性繊維性腫瘍の 1 例

\section{名古屋掖済会病院外科}

萩原康友、河野 弘、木村充志、米山文彦、木村桂子、芥川篤史、 尾辻英彦、明石久美子、清板和昭、長谷部圭史、長尾拓哉、前田 周良、福岡 恵、菜原聖実

症例は67歳男性。潰瘍性大腸炎にて近医通院中に右上腹部腫瘤を 指摘され、当院消化器科に紹介受診となった。初診時右上腹部に 弾性硬で可動性のある $5 \mathrm{~cm}$ 大の腫瘤を触れた。CTでは右上腹 部に長径 $11 \mathrm{~cm}$ の造影効果が不均一な多結節性充実性腫瘤を認め た。右胃大網動脈を feeding artery とし、drainage vein は副右結 腸静脈に流入していたため、大網原発腫瘍の診断で手術となった。 手術所見は右上腹部に大網に連続する八頭状の充実性腫瘤を認め た。周囲臟器への浸潤なく、血管を処理し腫湟を摘出した。経過 は良好で術後 4 日目に退院となった。病理所見では、紡錘型の核 をもち束状に増殖していた腫瘍細胞を認めた。c-kit陰性、CD34 陽性、BCL- 2 陽性、CD99陽性上り孤立性瀻維性腫瘍（SFT）と 判断した。SFTは非常にまれな間葉系腫瘍で主に胸膜から発生
する腫瘍である。検索しうる限り大網原発 SFTは 6 例のみ報告 されている。今回われわれは非常に稀な腸間膜原発SFT の症例 を経験したため、文献的考察を加え報告する。

63 乳癌術後に発生した後腹膜神経鞘腫の 1 切除例 愛知県がんセンター中央病院消化器外科

赤澤智之、小森康司、木村賢哉、木下敬史、伊藤誠二、安部哲也、 千田嘉毅、三澤一成、伊藤友一、植村則久、夏目誠治、川上次郎、 清水泰博

症例は40歳、女性。左乳癌術後の患者であり、フォローで行った $\mathrm{CT}$ にて腹腔内の腫瘤を指摘され当科紹介となった。CT上、右 腎門部に約 $60 \mathrm{~mm}$ 大の充実性腫瘍がみられ、下大静脈は左腹側へ 圧排されていた。辺縁の一部には層状の低吸収域がみられ後腹膜 原発の神経原生腫瘍が疑われた。術中所見：腫瘍は右腎下極付近 に存在しており、右尿管背側、右腸腰筋腹側、下大静脈右側に位 置していた。右腎との剥離は容易であった。右腸腰筋との癒着は 強かったが剥離を行い腫瘍を摘出した。術後経過は良好であり術 後12日目に退院となった。後腹膜に発生する神経鞘腫は比較的稀 な疾患であり、若干の文献的考察を加え報告する。 